\title{
Binding of ATP to vascular endothelial growth factor isoform VEGF-A 165 is essential for inducing proliferation of human umbilical vein endothelial cells
}

Ronald E Gast ${ }^{1}$, Simone König ${ }^{2}$, Karsten Rose ${ }^{1}$, Katja B Ferenz ${ }^{1}$ and Josef Krieglstein ${ }^{1 *}$

\begin{abstract}
Background: ATP binding is essential for the bioactivity of several growth factors including nerve growth factor, fibroblast growth factor-2 and brain-derived neurotrophic factor. Vascular endothelial growth factor isoform 165 (VEGF-A $\left.A_{165}\right)$ induces the proliferation of human umbilical vein endothelial cells, however a dependence on ATPbinding is currently unknown. The aim of the present study was to determine if ATP binding is essential for the bioactivity of VEGF-A 165 .

Results: We found evidence that ATP binding toVEGF-A $A_{165}$ induced a conformational change in the secondary structure of the growth factor. This binding appears to be significant at the biological level, as we found evidence that nanomolar levels of ATP $(4-8 \mathrm{~nm})$ are required for the VEGF- $\mathrm{A}_{165}$-induced proliferation of human umbilical vein endothelial cells. At these levels, purinergic signaling by ATP via P2 receptors can be excluded. Addition of alkaline phosphate to cell culture lowered the ATP concentration in the cell culture medium to $1.8 \mathrm{nM}$ and inhibited cell proliferation.
\end{abstract}

Conclusions: We propose that proliferation of endothelial cells is induced by a VEGF-A 165 -ATP complex, rather than VEGF-A 165 alone.

\section{Background}

Vascular endothelial growth factor isoform VEGF- $\mathrm{A}_{165}$ is a primarily endothelial cell-specific mitogen that plays a pivotal role in both vasculogenesis and angiogenesis $[1,2]$. As a key regulator of neovascularization it promotes embryonic development, wound healing and female reproductive functions [3-5]. The function of VEGF- $A_{165}$ is associated with various medical disorders, including tumor growth and metastasis, proliferative retinopathies and inflammatory conditions such as rheumatoid arthritis and psoriasis [6-9].

There are at least eight different splice forms of the VEGF-A gene with VEGF- $A_{121}$, VEGF- $A_{165}$ and VEGF$\mathrm{A}_{189}$ being the most abundantly expressed in humans [10-14]. All VEGF-A isoforms encode homodimeric

\footnotetext{
* Correspondence: krieglst@uni-muenster.de

${ }^{1}$ Institut für Pharmazeutische und Medizinische Chemie, Hittorfstraße 58-62, 48149 Münster, Germany

Full list of author information is available at the end of the article
}

proteins that are glycosylated and secreted. Signaling occurs through binding to the VEGF receptor 1 (Flt-1) and 2 (KDR), two structurally related receptor tyrosine kinases $[15,16]$. The splice forms of VEGF-A have varying affinity for heparan sulfate proteoglycans (HSPGs), depending on the different heparin-binding domains encoded by exons 6 and 7 [17-19]. The splice variant VEGF-A $A_{165}$ is thought to be most effective mitogen due to moderate heparin affinity encoded by the heparin binding domain of exon-7. This domain also facilitates the binding of VEGF- $\mathrm{A}_{165}$ to neuropilin 1 , a co-receptor which itself enhances binding of VEGF- $A_{165}$ to VEGFR2 $[20,21]$.

Binding to ATP has been shown to be important for a number of growth factors, including nerve growth factor (NGF), fibroblast growth factor-2 (FGF-2) and brainderived neurotrophic factor (BDNF) [22,23]. For BDNF, at least, this appears to be mediated by covalent binding, based on the results from mass spectrometry of BDNF- 
ATP complex with electrospray ionization (ESI) techniques. Other growth factor-ATP complexes were not stable under these ionization conditions, however have been detected using a more gentle ionization method, matrix assisted laser desorption/ionization (MALDI).

There is also evidence that the interaction of these factors with ATP is important for their bioactivity. For example, an interaction with ATP was proven to be a prerequisite for the neuroprotective activity of NGF and FGF2 [24,25]. Additionally, binding to ATP stabilized FGF-2 against proteolytic cleavage and thermal denaturation [26]. Although in many cases the ATP binding site and effect on protein structure is unkown, for NGF and FGF-2 at least, the nucleotide binding is thought to occur at the site of the heparin binding domain [25,27].

ATP levels are important for the nervous and vascular systems and are known to act synergistically with VEGF-A $A_{165}$ on endothelial cells [28-31]. In this study, we investigated the hypothesis that the bioactivity of VEGF-A $\mathrm{A}_{165}$ is dependent on ATP-binding, using radiolabeling and mass spectrometry techniques. To define its biological relevance, we investigated the influence of the extracellular ATP concentration on VEGF-A 165 -induced proliferation of human umbilical vein endothelial cells (HUVECs).

\section{Methods}

\section{Materials}

Adenosine-5'-triphosphate (ATP) disodium salt, alkaline phosphatase (AP; from bovine intestinal mucosa), benzamidine hydrochloride, dithiothreitol (DTT), heparin sodium salt (from bovine intestinal mucosa), imadazole, lysozyme (from chicken egg white), PMSF, plasmin (from human plasma) and Triton ${ }^{\circledR}-\mathrm{X} 100$ were purchased from Sigma-Aldrich (Taufkirchen, Germany). Sodium chloride and urea were from Merck (Darmstadt, Germany), Tween ${ }^{\circledR} 20$ and ethylenediamine tetraacetic acid (EDTA) disodium salt from SERVA (Heidelberg, Germany), Tris-HCl from USB (Cleveland, OH, USA) and guanidine hydrochloride from GERBU (Gaiberg, Germany).

\section{Production and purification of recombinant human VEGF-} $A_{165}$

Heterologous expression of the plasmid pET16bVEGFA165 in E. coli BL21(DE3) yielded recombinant human VEGF-A 165 (186 aa) comprising the N-terminal His-tag sequence, GlyHis 10 , followed by a Factor Xa cleavage site. Here, the translational product is referred to as VEGF-A 165 . The expression of the plasmid was performed as described previously [27]. It resulted in the formation of inclusion bodies which represented the primary source of the target protein. They were isolated and solubilized. To that end, frozen cell pellets of E. coli
BL21(DE3) pET16b-VEGFA165 were resuspended (Ultraturrax T 25; Jahnke \& Kunkel, Staufen, Germany) in lysis buffer (0.1 M Tris- $\mathrm{HCl} \mathrm{pH} 7.5,5 \mathrm{mM}$ EDTA, $150 \mathrm{mM} \mathrm{NaCl})$ containing lysozyme $(0.1 \%(\mathrm{w} / \mathrm{v}))$, phenylmethylsulfonyl fluoride and benzamidine (1 mM each). Following sonication on ice Triton ${ }^{\circledR}-\mathrm{X} 100(2 \%$ $(\mathrm{w} / \mathrm{v})), \mathrm{MgCl}_{2}(1 \mathrm{mM})$ and DNase I $(1 \mu \mathrm{L} / \mathrm{mL})$ were added for $30 \mathrm{~min}$ of incubation at $25^{\circ} \mathrm{C}$. Subsequently, inclusion bodies were collected by centrifugation $(47.800$ $\left.\times \mathrm{g}, 15 \mathrm{~min}, 4^{\circ} \mathrm{C}\right)$ and washed twice with buffer $(0.1 \%$ (v/v) Tween ${ }^{\circledR} 20,150 \mathrm{mM} \mathrm{NaCl}$ ) and double-destilled water $\left(\mathrm{ddH}_{2} \mathrm{O}\right)$ prior to solubilisation in $8 \mathrm{M}$ urea, 50 $\mathrm{mM}$ Tris- $\mathrm{HCl}(\mathrm{pH} 8)$ and $20 \mathrm{mM}$ 2-mercapotethanol. VEGF-A 165 was purified from this solution by immobilized metal ion chromatography. For that purpose, solubilized inclusion bodies were applied to an Econocolumn (BioRad, Hercules, CA, USA) filled with $\mathrm{Ni}^{2}$ ${ }^{+}$-nitrilotriacetic acid agarose (Qiagen, Hilden, Germany), washed and eluted using $250 \mathrm{mM}$ imadazole according to the manufacturer's instructions. For renaturation, pooled fractions of VEGF-A 165 were reduced with DTT $(20 \mathrm{mM})$ and dialysed against renaturation buffer (500 mM guanidine hydrochloride, $100 \mathrm{mM}$ Tris$\mathrm{HCl}$ pH 9.0, 2 mM EDTA, cysteine/cystine redox system (5:1 ratio; $5 \mathrm{mM}$ cysteine, $1 \mathrm{mM}$ cystine)). Finally, refolded, dimeric VEGF-A 165 was dialyzed against 100 $\mathrm{mM}$ sodium acetate buffer $(\mathrm{pH} 5)$ and concentrated using Amicon Ultra centrifugal filter devices (10 kDa molecular weight cut-off; Millipore, Bedford, MA, USA).

\section{Labeling of VEGF-A ${ }_{165}$ with $\left[\gamma^{32}\right.$ P]ATP and $\left[\alpha^{32}\right.$ P]ATP}

For labeling, $3 \mu \mathrm{g}$ VEGF-A 165 (unless otherwise noted) was incubated with $5 \mu \mathrm{Ci}$ each of $\left[\gamma-{ }^{32} \mathrm{P}\right] \mathrm{ATP}$ or $\left[\alpha-{ }^{32} \mathrm{P}\right]$ ATP (Hartmann Analytic, Braunschweig, Germany) and combined with $0.01 \mathrm{mM}$ non-radioactive ATP (optionally containing $0.1 \mathrm{mM} \mathrm{MgCl}_{2}$ ). Incubation was performed in $25 \mathrm{mM}$ Tris- $\mathrm{HCl}$ (pH 7.5, total volume 15 $\left.\mu \mathrm{L}, 37^{\circ} \mathrm{C}, 15 \mathrm{~min}\right)$. For treatment of labeled VEGF-A 165 with heparin $(1,10$ or $100 \mu \mathrm{g} / \mathrm{mL})$, sodium chloride $(100 \mathrm{mM})$ or AP $(300 \mathrm{ng} / 15 \mu \mathrm{L})$ incubation was continued for additional 15 min upon addition of each compound. Proteins were separated by reducing sodium dodecyl sulfate polyacrylamide gel electrophoresis (SDSPAGE; 17.5\%). Minigels were vacuum-dried. Radiolabeling was detected using a BAS-1800 II reader and BASMS 2325 imaging plates (Fujifilm, Tokyo, Japan) and analyzed with AIDA Image Analyzer software (version 3.21.001, Raytest GmbH, Straubenhardt, Germany).

\section{Plasmin digestion of VEGF-A 165 labeled with ATP}

$2 \mu \mathrm{g}(6 \mu \mathrm{M})$ VEGF-A 165 was incubated in the presence or absence of $20 \mu \mathrm{M}$ ATP in $25 \mathrm{mM}$ Tris- $\mathrm{HCl}$ ( $\mathrm{pH} 7.5)$ at $37^{\circ} \mathrm{C}$ for $15 \mathrm{~min}$. Subsequently, $300 \mathrm{ng}$ plasmin was added for proteolytic cleavage and incubation was 
continued for additional 120 min. For comparison with non-digested growth factor, $2 \mu \mathrm{g}$ VEGF-A $\mathrm{A}_{165}$ were treated in the same way except that ATP and plasmin were omitted. Protein fragments were separated by reducing SDS-PAGE (17.5\%) and visualized by silver staining [32].

\section{Circular dichroism (CD) spectroscopy}

Far-UV CD spectra (195-250 nm) were recorded at 100 $\mathrm{nm} / \mathrm{min}$ using a Jasco-J600 spectropolarimeter and a 0.1 $\mathrm{cm}$ sample cell $\left(25^{\circ} \mathrm{C}, 4\right.$ accumulations each). Data point resolution and bandwidth were set to $1 \mathrm{~nm}$, sensitivity to $50 \mathrm{mdeg}$. Samples containing $40 \mu \mathrm{M}$ VEGF- $\mathrm{A}_{165}$ were pre-incubated with or without a twofold excess of ATP $(80 \mu \mathrm{M})$ in $25 \mathrm{mM}$ Tris- $\mathrm{HCl}\left(\mathrm{pH} 7.5,37^{\circ} \mathrm{C}, 15\right.$ min). Final protein $\mathrm{CD}$ spectra were background-corrected with regard to absorption caused by ATP and buffer components. Data were evaluated using J-700 for Windows Standard Analysis software.

\section{MALDI-TOF MS}

For detection of the VEGF-A 165 -ATP complex, MALDITOF MS was performed according to König et al. [23] with slight modifications. VEGF- $\mathrm{A}_{165}$ and its complexes were purified by reversed phase chromatography using $\mathrm{C}_{18}$-ZipTip pipet tips (Millipore, Bedford, MA, USA). Pipet tips were washed with elution solvent (80\% methanol, $0.1 \%$ acetic acid) and equilibrated with aqueous solvent ( $5 \%$ methanol, $0.1 \%$ acetic acid) before use. For purification, samples containing $27.5 \mu \mathrm{M}$ VEGF- $\mathrm{A}_{165}$, optionally combined with ATP $(30 \mu \mathrm{M})$ and $\mathrm{MgCl}_{2}(60$ $\mu \mathrm{M})$, were applied, rinsed with aqueous solvent and eluted into $5 \mu \mathrm{L}$ of elution solvent. Purified samples $(0.5$ $\mu \mathrm{L}$ ) were spotted onto a MALDI-target coated with 0.5 $\mu \mathrm{L}$ of $1 \%$ sinapinic acid in acetone. Subsequently, $0.5 \mu \mathrm{L}$ of $1 \%$ sinapinic acid in $40 \%$ acetonitrile was added. Spectra were obtained with MALDImicroMX (Waters Corp., Manchester, UK).

\section{Cell proliferation assay}

HUVECs (Promocell, Heidelberg, Germany) were seeded in 96-well plates at $8 \times 10^{4}$ cells/well containing $100 \mu \mathrm{L}$ of Endothelial Cell Growth Medium with supplements (EGM; Promocell, Heidelberg, Germany). Seeded HUVECs were cultured under standard conditions (humidified atmosphere, $5 \%(\mathrm{v} / \mathrm{v}) \mathrm{CO}_{2}, 37^{\circ} \mathrm{C}$ ) for $24 \mathrm{~h}$ before EGM was replaced by $100 \mu \mathrm{L}$ Endothelial Cell Basal Medium (EBM; Promocell, Heidelberg, Germany) containing $0.1 \%(\mathrm{w} / \mathrm{v})$ bovine serum albumin (BSA). After $1 \mathrm{~h}$ of incubation, media were replaced once more by $100 \mu \mathrm{L}$ EBM containing VEGF-A $165(20 \mathrm{ng} / \mathrm{mL})$ instead of BSA. In addition, AP (Sigma-Aldrich, Taufkirchen, Germany) was applied to selected samples at 40,80 or $160 \mathrm{ng} / \mathrm{mL}$ along with thegrowth factorand incubation was continued for $48 \mathrm{~h}$. Subsequently, cell culture media were taken from separate samples treated in the same manner for measurement of extracellular ATP.

Finally, proliferation of HUVECs was determined using the CellTiter $96^{\circledR}$ Aqueous One Solution Cell Proliferation Assay kit (Promega, Mannheim, Germany) according to the manufacturer's instructions. To that end, $20 \mu \mathrm{L}$ of CellTiter $96^{\circledR}$ Aqueous One Solution was added to each well to be incubated for additional $3 \mathrm{~h}$. The number of viable cells was directly proportional to the absorbance of a colored formazan product determined colorimetrically (Lambda Scan, MWG Biotech, Ebersberg, Germany) at $490 \mathrm{~nm}$. Values are presented as means \pm standard deviation (SD; $\mathrm{n}=9$ ).

\section{Luminometric measurement of extracellular ATP}

Extracellular ATP was determined in cell-free samples of cell culture media ( $80 \mu \mathrm{L}$ each) employing the ATP Kit SL (sensitivity: $10^{-6}-10^{-12} \mathrm{~mol} / \mathrm{L}$; BioThema, Handen, Sweden) according to the manufacturer's instructions. The bioluminescent reaction is based on the luciferasecatalyzed oxidation of luciferin in the presence of oxygen and ATP. Besides AMP, pyrophosphate and carbon dioxide, oxiluciferin is produced emitting light at 560 $\mathrm{nm}$ to be measured luminometrically. Light emission is proportional to the amount of ATP and was measured in a two-step procedure using an FB 12 Single tube Luminometer (Berthold Detection Systems, Pforzheim, Germany). First, the light intensity of the samples $\left(\mathrm{I}_{\mathrm{smp}}\right)$ was quantified as relative light units/second (RLU/s). Then, an internal ATP standard (final concentration 10 $\mu \mathrm{M})$ was added to each sample and light intensity was quantified again to give $\mathrm{I}_{\mathrm{smp}+\mathrm{std}}$. This procedure allowed for the conversion of light intensity (RLU/s) to concentration of ATP $(\mathrm{mol} / \mathrm{L})$ by the following equation:

$$
\operatorname{ATP}_{\text {smp }}=12.5 \cdot\left(10^{-7} \cdot I_{s m p}\right):\left(I_{\text {smp+std }}-I_{s m p}\right) .
$$

The assay was performed in triplicate.

\section{Statistical analysis}

Data are expressed as means \pm SD based on one-way analysis of variance (ANOVA) followed by Scheffé's test. A probability value $(\mathrm{P})$ of less than 0.01 was considered statistically significant. Figure legends specify statistically significant differences between experimental groups at probability values of $\mathrm{p}<0.01$ and $\mathrm{p}<0.001$. Analysis was performed using WinSTAT.

\section{Results}

Binding of ATP to VEGF-A $A_{165}$

In order to evaluate the binding of ATP to VEGF-A $\mathrm{A}_{165}$, VEGF- $\mathrm{A}_{165}$ was radiolabeled by $\left[\gamma-{ }^{32} \mathrm{P}\right] \mathrm{ATP}$ and $\left[\alpha-{ }^{32} \mathrm{P}\right]$ ATP. The use of $\left[\gamma_{-}{ }^{32} \mathrm{P}\right] \mathrm{ATP}$ as well as $\left[\alpha-{ }^{32} \mathrm{P}\right] \mathrm{ATP}$ 
allowed to distinguish between binding of ATP to VEGF-A $A_{165}$ and autophosphorylation. The influence of divalent cations $\left(\mathrm{Mg}^{2+}\right)$ was also tested. Signal is detected for both $\left[\gamma_{-}{ }^{32} \mathrm{P}\right]$ ATP- and $\left[\alpha-{ }^{32} \mathrm{P}\right]$ ATP-labeled growth factor independently of the presence of $\mathrm{Mg}^{2+}$ (Figure 1). ATP appeared to be bound to growth factor by non-covalent interaction via the phosphate residues of the nucleotide $[23,25,27]$. In contrast to a covalent modification, an ionic interaction can be influenced by an increase in ionic strength. Labeling of VEGF-A 165 with $\left[\gamma_{-}{ }^{32} \mathrm{P}\right] \mathrm{ATP}$ and $\left[\alpha-{ }^{32} \mathrm{P}\right] \mathrm{ATP}$, respectively, was suppressed by $100 \mathrm{mM} \mathrm{NaCl}$ added to the reaction mixture prior to the nucleotides (Figure 2). Once the complex had formed, however, it proved to be fairly resistant to the salt concentration.

VEGF- $A_{165}$ contains a heparin-binding domain which is critical for its mitogenic activity and storage in the extracellular matrix via HSPGs [33]. Interestingly, heparin affected binding of ATP to FGF-2 due to overlapping binding sites [27]. Competition experiments revealed that heparin also interfered with the binding of ATP to VEGF$\mathrm{A}_{165} .10 \mu \mathrm{g} / \mathrm{mL}$ heparin added to the reaction mixture prior to $\left[\gamma_{-}{ }^{32} \mathrm{P}\right] \mathrm{ATP}$ reduced radiolabeling of VEGF-A markedly (Figure 3A). $100 \mu \mathrm{g} / \mathrm{mL}$ heparin inhibited $\left[\gamma^{32} \mathrm{P}\right]$ ATP binding to the mitogen completely. However, when $\left[\gamma_{-}{ }^{32} \mathrm{P}\right] \mathrm{ATP}$ was added to the reaction mixture prior to heparin $(100 \mu \mathrm{g} / \mathrm{mL})$, only a slight decrease in radiolabeling of VEGF- $\mathrm{A}_{165}$ occurred (Figure 3B, lane 3).

\section{MALDI-TOF MS of the VEGF-A $A_{165}$-ATP complex}

MALDI-TOF MS was performed employing soft conditions as described previously [23]. This approach was suitable for the detection of labile nucleotide-protein complexes. Sample preparations using low-acidic reversed phase chromatography and acid-free matrix assisted in retaining the non-covalent interaction. The measurements were performed using the high-mass detector in order to observe the VEGF- $\mathrm{A}_{165}$ dimer as the bioactive species present in vivo [1].

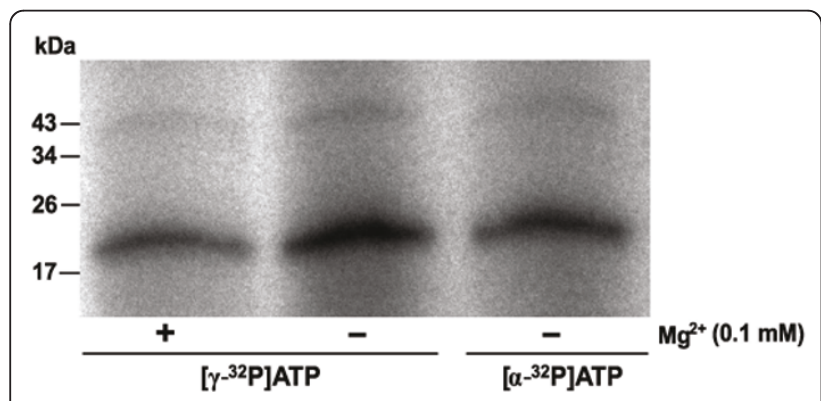

Figure 1 Labeling of VEGF-A $A_{165}$ with $\left[\gamma^{-32}\right.$ P]ATP and $\left[\alpha^{32}\right.$ P]ATP. VEGF-A $165(2 \mu \mathrm{g})$ was incubated with radioactive ATP $(5 \mu \mathrm{Ci})$ in Tris$\mathrm{HCl}(\mathrm{pH} 7.5)$ at $37^{\circ} \mathrm{C} . \mathrm{MgCl}_{2}(0.1 \mathrm{mM})$ was added prior to ATP (+). After 15 min of incubation SDS-PAGE and autoradiography were performed.

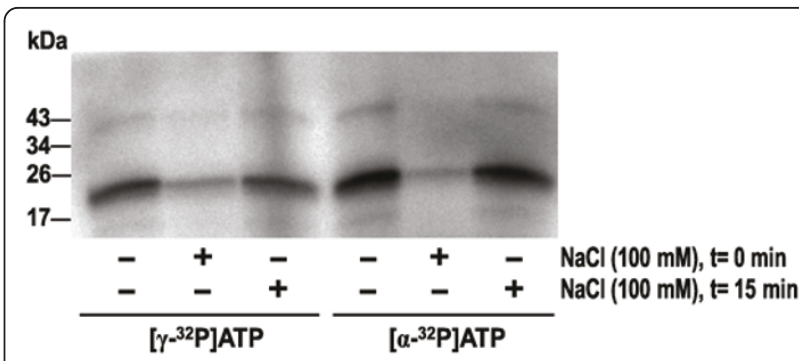

Figure 2 Effect of increased ionic strength on labeling of

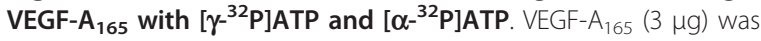
incubated with radioactive ATP $(5 \mu \mathrm{Ci})$ in Tris- $\mathrm{HCl}(\mathrm{pH} 7.5)$ at $37^{\circ} \mathrm{C}$ for $30 \mathrm{~min} . \mathrm{NaCl}(100 \mathrm{mM})$ was added at times $(\mathrm{t})$ indicated.

The incubation of VEGF- $\mathrm{A}_{165}$ with ATP $(507.2 \mathrm{~g} / \mathrm{mol})$ caused considerable peak broadening as compared to pure VEGF-A 165 (21673 Da) (Figure 4). The shift in mass corresponded to the addition of one molecule of ATP per molecule of growth factor and did not differ when $\mathrm{Mg}^{2+}$ was added to the incubation mixture. The dimer was also affected by ATP, but the number of bound ATP molecules could not be clearly defined due to low signal intensity.

\section{ATP induces a conformational change of VEGF- $\mathrm{A}_{165}$}

Far-UV CD spectroscopy was carried out in order to investigate a putative effect of ATP binding on the secondary structure of VEGF- $\mathrm{A}_{165}$. Thus, the CD of VEGF- $\mathrm{A}_{165}$

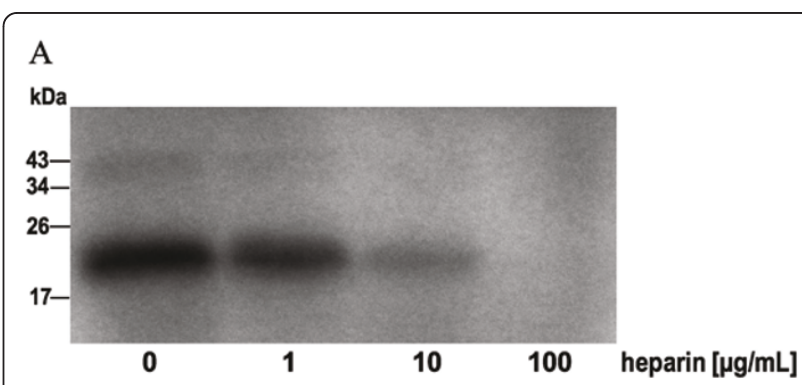

B

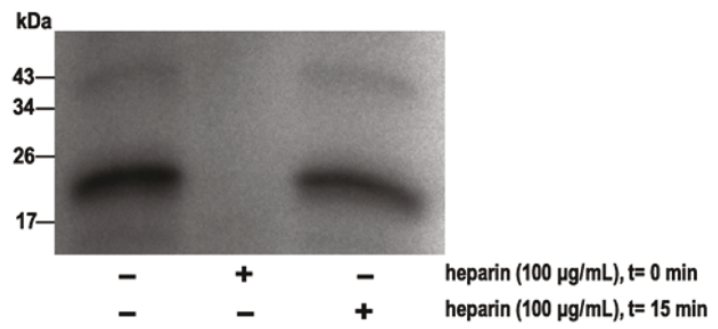

Figure 3 Competition of heparin and $\left[\gamma^{32}\right.$ P $]$ ATP for binding to VEGF-A $\mathbf{1}_{\mathbf{1 6 5}}$. VEGF-A $165(3 \mu \mathrm{g})$ was labeled with $\left[\gamma^{-32} \mathrm{P}\right] \mathrm{ATP}(5 \mu \mathrm{Ci})$ in Tris- $\mathrm{HCl}(\mathrm{pH} 7.5)$ at $37^{\circ} \mathrm{C}$ for $30 \mathrm{~min}$. (A) Heparin was added prior to ATP to give final concentrations of 1 to $100 \mu \mathrm{g} / \mathrm{mL}$. (B) Heparin was added at a fixed concentration of $100 \mu \mathrm{g} / \mathrm{mL}$ and times ( $\mathrm{t}$ ) indicated. 


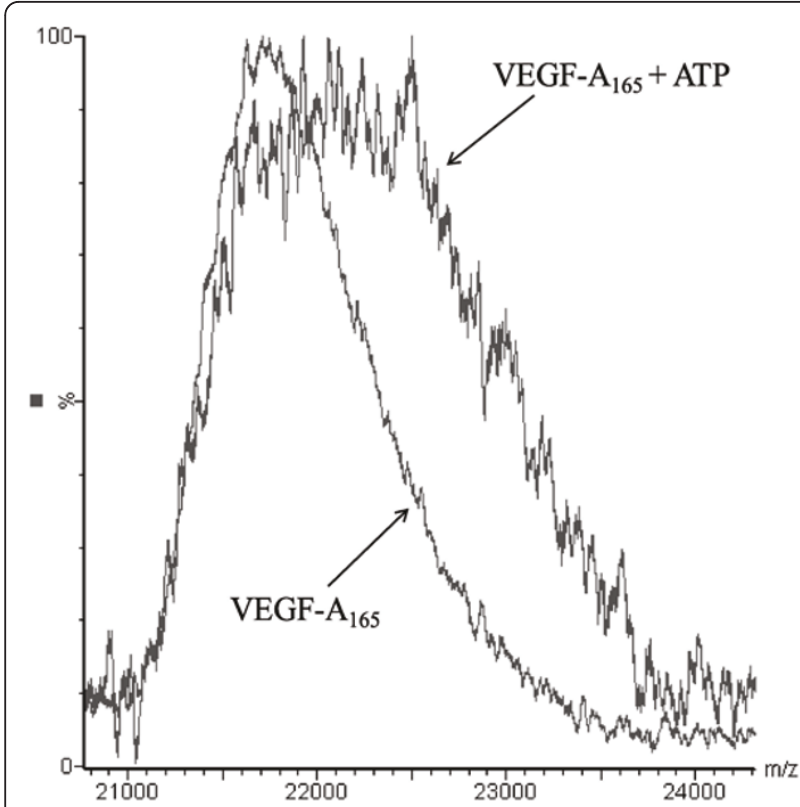

Figure 4 MALDI-TOF spectrum overlay of VEGF-A 165 and the

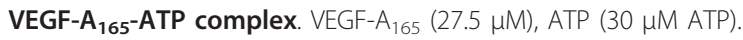
ATP $(507.2 \mathrm{~g} / \mathrm{mol})$ causes peak broadening due to complex formation with VEGF-A $A_{165}$. The further addition of $60 \mu \mathrm{M} \mathrm{Mg}^{2+}$ has no measurable impact on the spectrum (data not shown).

was measured without or with a twofold molar excess of ATP. The graph obtained for (His) ${ }_{10}$-tagged rhVEGF- $\mathrm{A}_{165}$ (Figure 5) was similar to that reported in the literature for untagged rhVEGF- $\mathrm{A}_{165}$ reflecting a typical graph of a protein rich in $\beta$-structure $[34,35]$. The latter accounts for about $40 \%$ of the secondary structure of rhVEGF- $\mathrm{A}_{165}$. A first maximum close to the base level below $200 \mathrm{~nm}$ fell to a minimal molar ellipticity at $207 \mathrm{~nm}$ and rose again to a second maximum at $250 \mathrm{~nm}$. In contrast, the CD spectrum

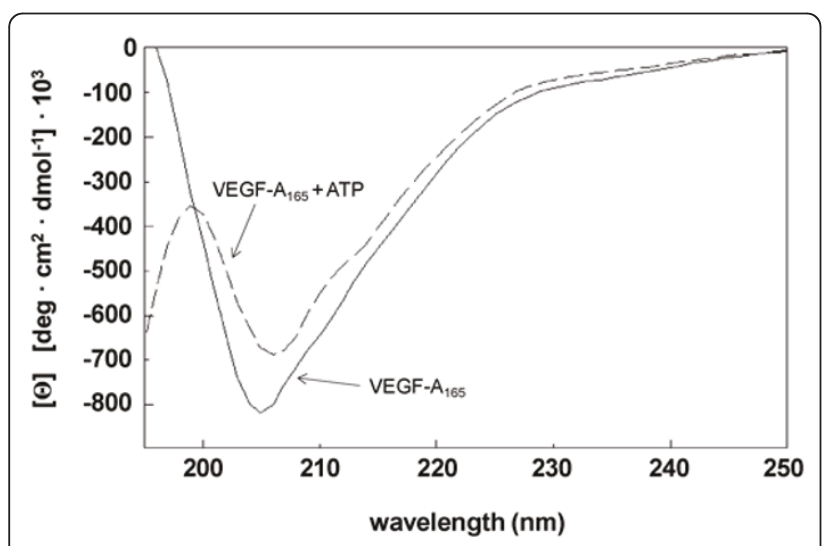

Figure 5 ATP induces a conformational change in the secondary structure of VEGF- $\mathbf{A}_{165}$. Far-UV CD spectra were recorded of VEGF-A $A_{165}(40 \mu \mathrm{M})$ pre-incubated without or with ATP $(80 \mu \mathrm{M})$. Pre-incubation was performed in Tris- $\mathrm{HCl}(\mathrm{pH} 7.5)$ at $37^{\circ} \mathrm{C}$ for $15 \mathrm{~min}$. of VEGF-A 165 with ATP exhibited a significant decrease in molar ellipticity towards the base level above $200 \mathrm{~nm}$, especially at $207 \mathrm{~nm}$ (Figure 5, dashed line). This result suggested reduced $\beta$-sheet content in the secondary structure of the growth factor compensated for by an increase in random coil structure.

\section{Binding of ATP does not protect VEGF-A $\mathrm{A}_{165}$ from plasmin cleavage}

The serine protease plasmin cleaves VEGF- $\mathrm{A}_{165}$ solely at the $\mathrm{Arg}^{110}-\mathrm{Ala}^{111}$ bond yielding VEGF- $\mathrm{A}_{110}$ and an Nterminal fragment consisting of 55 residues including the heparin-binding domains [33]. Compared to VEGF$\mathrm{A}_{165}$, VEGF- $\mathrm{A}_{110}$ exhibits a markedly reduced mitogenic activity on HUVECs. In the case of FGF-2, ATP binding protected effectively against proteolytic digestion by proteases including plasmin [26]. This was not true for VEGF-A $_{165}$ (Figure 6). Plasmin digestion of VEGF- $A_{165}$ and VEGF- $\mathrm{A}_{165}$ pre-incubated with ATP generated a most abundant cleavage product of $15 \mathrm{kDa}$ in all samples which corresponded to the molecular mass of (His)

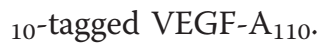

Mitogenic activity of VEGF-A $A_{165}$ on HUVECs requires ATP NGF and FGF-2 protected cultured neurons against damage by staurosporine only if ATP at concentrations above $1 \mathrm{nM}$ were present in the culture medium $[24,25]$. In order to investigate this effect for VEGF$\mathrm{A}_{165}$, we compared the proliferative effect of VEGF- $\mathrm{A}_{165}$ in untreated cultures of HUVECs with that at reduced ATP level. ATP levels in the cell culture medium were lowered by AP and measured luminometrically. AP dephosphorylated both free ATP and $\left[\gamma_{-}{ }^{32} \mathrm{P}\right]$ ATP or $[\alpha-$ ${ }^{32}$ P]ATP bound to VEGF-A 165 (Figure 7).

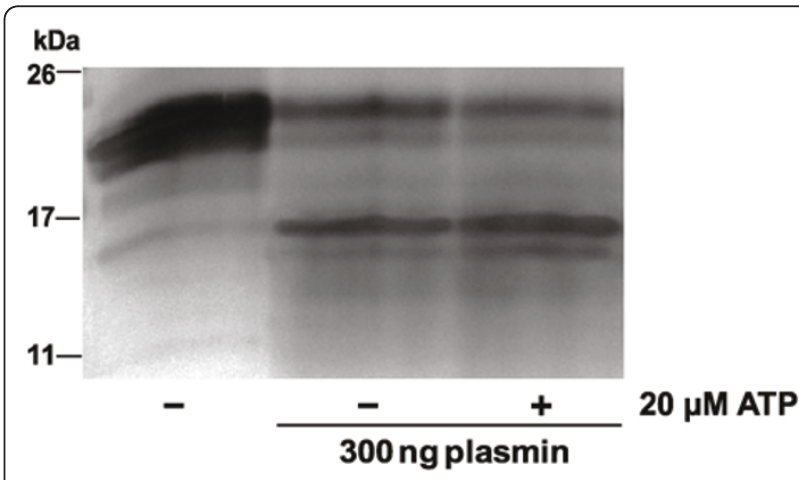

Figure 6 Proteolytic cleavage of ATP-labeled and unlabeled VEGF- $A_{165}$ by plasmin. VEGF-A $165(6 \mu M)$ was preincubated in Tris$\mathrm{HCl}(\mathrm{pH} 7.5)$ without or with ATP $(20 \mu \mathrm{M})$ at $37^{\circ} \mathrm{C}$. After 15 min of pre-incubation, $300 \mathrm{ng}$ of plasmin was added to one sample (lane 3) and incubation of all samples was continued for an additional $120 \mathrm{~min}$. Reaction products were visualized by SDS-PAGE and silver staining. 


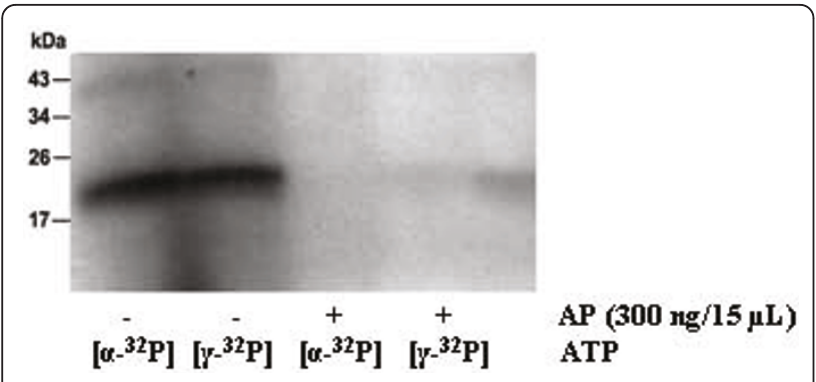

Figure 7 AP hydrolyzes $\left[\gamma_{-}{ }^{32} \mathrm{P}\right]$ ATP and $\left[\alpha^{-}{ }^{32} \mathrm{P}\right] \mathrm{ATP}$ bound to VEGF-A $\mathbf{1}_{165}$. VEGF-A $A_{165}(15 \mu \mathrm{M})$ was labeled with radioactive ATP (5 $\mu \mathrm{Ci})$ in Tris- $\mathrm{HCl}\left(\mathrm{pH} \mathrm{7.5)}\right.$ at $37^{\circ} \mathrm{C}$ for $15 \mathrm{~min}$. After labeling $(\mathrm{t}=15$ min), $300 \mathrm{ng}$ of AP was added (lane 3 and 4). Incubation of all samples was continued for an additional period of 15 min followed by SDS-PAGE and autoradiography.

VEGF-A $\mathrm{A}_{165}(20 \mathrm{ng} / \mathrm{mL})$ increased the number of viable HUVECs in the positive control significantly (Figure 8A, VEGF). $40 \mathrm{ng} / \mathrm{mL}$ AP reduced eATP to $3.82 \mathrm{nM}$ (positive control: $8.30 \mathrm{nM}$ ) which did not impair the mitogenic activity of VEGF-A 165 . However, higher concentrations of

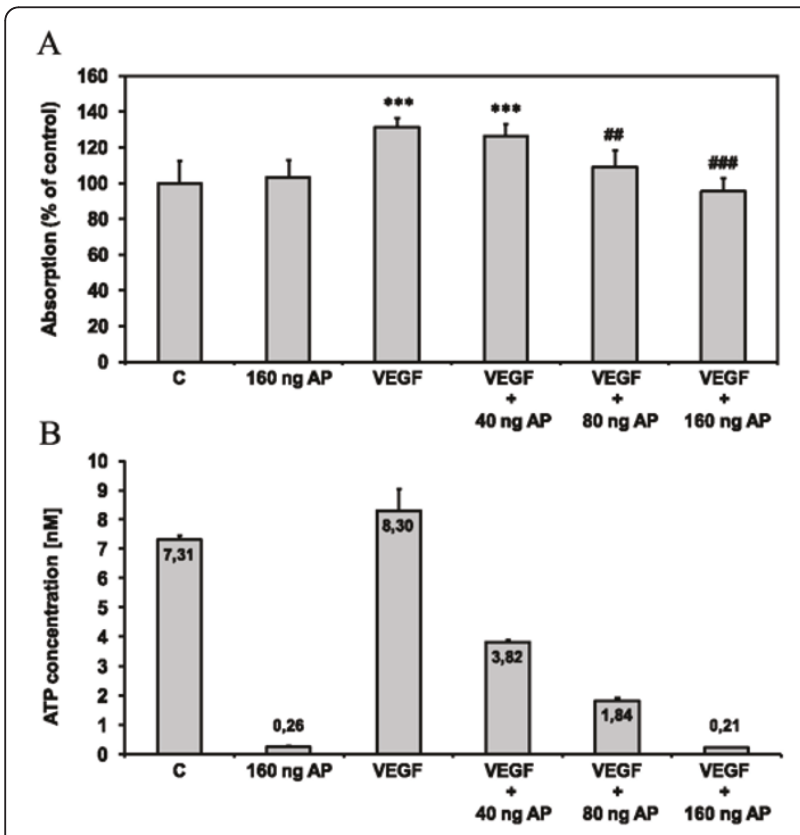

Figure 8 VEGF- $A_{165}$ fails to induce proliferation of HUVECs at low extracellular ATP concentrations. (A) HUVECs were cultured in serum-free EBM (C) or serum-free EBM containing VEGF-A 165 (20 $\mathrm{ng} / \mathrm{mL})$, AP $(160 \mathrm{ng} / \mathrm{mL})$ or VEGF-A $165(20 \mathrm{ng} / \mathrm{mL})$ combined with $\mathrm{AP}$ at concentrations increasing from $40 \mathrm{ng} / \mathrm{mL}$ to $160 \mathrm{ng} / \mathrm{mL}$. After $48 \mathrm{~h}$ of incubation CellTiter $96^{\circledR}$ Aqueous One Solution Cell Proliferation Assay was performed. The absorption of a colored formazan product measured colorimetrically is proportional to the number of viable cells. Values are presented as means $\pm S D(n=9)$. ${ }^{* * *} \mathrm{p}<0.001$ vs. $C_{1}{ }^{\# \#} \mathrm{p}<0.001$ and ${ }^{\# \#} \mathrm{p}<0.01$ vs. VEGF (ANOVA, Scheffé's test). (B) ATP concentrations corresponding to (a) were analyzed luminometrically $(n=3)$ in the HUVEC culture medium after $48 \mathrm{~h}$ of incubation.
AP (80 ng/mL, $160 \mathrm{ng} / \mathrm{mL}$ ) inhibited HUVEC proliferation by VEGF-A $\mathrm{A}_{165}$ due to lowering of ATP levels to 1.84 $\mathrm{nM}$ and $0.21 \mathrm{nM}$, respectively (Figure $8 \mathrm{~B}$ ), in the cell culture medium. AP (160 ng/mL) added without exogeneous VEGF- $\mathrm{A}_{165}$ did not influence HUVEC viability despite reducing eATP effectively to $0.26 \mathrm{nM}$. In line with the data obtained for NGF and FGF-2, these results proved that VEGF- $\mathrm{A}_{165}$ required eATP in the low nanomolar range to act mitogenically on HUVECs.

\section{Discussion}

In previous work it has been demonstrated that growth factors such as NGF, BDNF and FGF-2 bind ATP and form non-covalent nucleotide-protein complexes [22,23] which are essential for neuroprotective activity in vitro $[24,25]$. In the case of FGF-2, binding of ATP also imparts enhanced proteolytic and thermal resistance [26]. In the present study, we detected binding of ATP to VEGF-A $A_{165}$, the predominant growth factor involved in neovascularization. Both radiolabeling (Figure 1) and mass spectrometry (Figure 4) analyses suggested that ATP bound to VEGF- $\mathrm{A}_{165}$ is independent of $\mathrm{Mg}^{2+}$-ions. The VEGF-A 165 -ATP complex appears to be extremely stable, remaining intact after denaturing SDS-PAGE, solid phase extraction and mass spectrometry techniques. In addition, an increase in ionic strength caused only a minor dissociation of the complex (Figure 2).

The most physiologically important form of ATP is thought to be the ATP/ $\mathrm{Mg}^{2+}$-complex, which is the predominant form of the nucleotide in tissue. Although our mass spectrometry analyses provide strong evidence that ATP bound to VEGF- $\mathrm{A}_{165}$ independently of $\mathrm{Mg}^{2+}$-ions, labeling of VEGF-A $\mathrm{A}_{165}$ with $\left[\gamma^{32} \mathrm{P}\right] \mathrm{ATP}$ could also be observed with $0.1 \mathrm{mM} \mathrm{MgCl} 2$ in the reaction buffer (data not shown). This is also true for labeling of the growth factor NGF [25]. Such ATP/ $\mathrm{Mg}^{2+} /$ growth factor complexes were identified by MALDI-TOF analysis of the growth factors FGF2 and NGF recently [23]. Radiolabeling of NGF with ATP is also possible in buffers containing $\mathrm{Ca}^{2+}, \mathrm{Mg}^{2+}, \mathrm{Mn}^{2+}$ or $\mathrm{Ni}^{2+}$, respectively [25]. Taken together, this indicates that VEGF-A 165 also forms a complex with ATP at physiological $\mathrm{Mg}^{2}$ ${ }^{+}$-concentrations.

Additionally, the recently discovered stabilization of FGF2 by ATP is also present when using $\mathrm{Mg}^{2+}$-ions [36]. This observed stabilizing effect of ATP on the growth factor is present at $\mathrm{Mg}^{2+}$ concentrations of 0.1 $\mathrm{mM}$. This indicates that under these conditions ATP/ $\mathrm{Mg}^{2+}$ binds to FGF2 and that this physiological ATP/ cation complex protects FGF2 against degradation, too. The effect of ectonucleases on the VEGF-A 165 -ATP complex also remains unknown. Our results suggest that the ATP bound to VEGF-A 165 was not only completely susceptible to cleavage by alkaline phosphatase 
(Figure 7), but also moderately susceptible to apyrase (data not shown).

Our results are consistent with the theory that growth factors bind ATP despite the absence of classic ATP binding site. Nevertheless, NGF, FGF-2 and VEGF-A 165 contain heparin binding domains, characterized by clusters of basic residues [37-39], which may interact with the negatively charged phosphate residues of ATP. The removal of these basic residues by site-directed mutagenesis of NGF and FGF-2 has been shown to drastically reduced both ATP binding and neuroprotective activity $[25,27,40]$. Heparin has been shown to suppress the binding of ATP to VEGF-A 165 (Figure 3), however does not cause the existing VEGF-A 165 -ATP complex to dissociate. Nevertheless, the competition between ATP and heparin for binding to VEGF- $\mathrm{A}_{165}$ is likely to effect the interaction with the VEGF receptor or storage in the extracellular matrix.

Our results strongly suggest that ATP binding induces a conformational change in the secondary structure of VEGF-A $A_{165}$. We propose that this conformational change is responsible for the increased bioactivity of the VEGF- $_{165}$-ATP complex, resulting in improved ligandreceptor interaction (Figure 5). The location at which ATP binds VEGF- $\mathrm{A}_{165}$, as well as the exact nature of the conformational change remains unknown.

Brandner et al. [34] demonstrated that heparan sulfate induced a conformational change in glycosylated VEGF$\mathrm{A}_{165}$ but not in the non-glycosylated form. In addition, they showed that heparin stabilized both glycosylated and non-glycosylated VEGF- $A_{165}$ against chaotropic or thermal denaturation without inducing any conformational change. This implies that the competition of ATP and heparin (HSPGs) for binding to the mitogen is of biological relevance. Further studies have to be undertaken in order to define exactly where ATP is bound providing a basis for elucidating putative complex-receptor interactions.

We found no evidence that ATP binding protects VEGF- $\mathrm{A}_{165}$ against plasmin cleavage (Figure 6), as previously suggested for FGF-2 [26]. We therefore propose that the biological activity of the VEGF- $\mathrm{A}_{165}$-ATP complex is due to improved receptor binding, and not due to increased stability of the growth factor. Supporting this theory, VEGF- $\mathrm{A}_{165}$ failed to induce HUVEC proliferation when the ATP concentration in the cell culture media was too low (Figure 8). This result corresponded to the minimal concentration of eATP required for the neuroprotective activity of NGF and FGF-2, which was determined to be approximately $1 \mathrm{nM}[24,25]$.

In our cell culture experiments, alkaline phosphatase was required to lower the concentration of ATP to levels that affected cell proliferation. It is feasible that high concentrations of alkaline phosphatase had independent effects, and we cannot discount the possibility of minor contamination with proteases. Alkaline phosphatase added without exogeneous VEGF-A $\mathrm{A}_{165}$ did not influence HUVEC viability (despite reducing eATP levels to 0.26 nM; Figure 8). Therefore, we believe side effects of alkaline phosphates at these concentrations are unlikely. This is in line with investigations with other growth factors like FGF2 [24] and NGF [25] that demonstrated similar results when using alkaline phosphatase to lower eATPconcentrations.

A completely different observation was made when using another growth factor, granulocyte colony stimulating factor (GCSF). This factor does not bind ATP and the neuroprotective activity of GCSF is not influenced by degradation of extracellular ATP by alkaline phosphatase (data not shown). This is in contrast to the situation with the ATP-binding growth factors FGF2 and NGF, where an extracellular ATP-concentration above about $1 \mathrm{nM}$ is essential for the neuroprotective activity of these growth factors $[24,25]$. However, this is plausible in the context of our hypothesis that ATP-growth factor interaction is essential for the activity of ATP-binding growth factors but not important for non-ATP-binding growth factors like GCSF. It is therefore reasonable to assume that the observed inhibition of HUVEC proliferation by VEGF$\mathrm{A}_{165}$ was due to the low ATP levels caused by alkaline phosphatase, which prevented the formation of the presumed biologically active VEGF- $\mathrm{A}_{165}$-ATP complex.

It is known that eATP can act synergistically with angiogenic growth factors including VEGF- $\mathrm{A}_{165}$ via $\mathrm{P} 2 \mathrm{Y}$ receptor signaling [30]. Even in the absence of VEGF$\mathrm{A}_{165}$, the nucleotide itself is capable of P2 $\mathrm{Y}_{1 / 2}$-VEGFR2 transactivation, inducing endothelial cell proliferation [31,41]. Given that activation of P2X and P2Y receptors requires eATP in the micromolar range [42], isolated effects of eATP mediated by purinergic receptor signaling are unlikely to contribute to the experimental results obtained from our model (Figure 8). We have clearly shown that ATP is tightly bound to VEGF- $\mathrm{A}_{165}$ and a critical concentration of ATP above $1.8 \mathrm{nM}$ is required for bioactivity. Based on these results, the VEGF- $\mathrm{A}_{165^{-}}$ ATP complex and not VEGF- $\mathrm{A}_{165}$ by itself appears to be the active ligand causing the proliferative effects under cell culture conditions. Both VEGF- $\mathrm{A}_{165}$-ATP complex formation and the putative interaction with its receptor remain to be elucidated in vivo.

\section{Conclusions}

For the first time we provided ample evidence that ATP binds to VEGF-A 165 . Binding of ATP most likely involves basic residues within the heparin binding domain and constitutes a prerequisite for the proliferative activity of VEGF- $\mathrm{A}_{165}$. 


\section{List of abbreviations}

The abbreviations used are: AP: alkaline phosphatase; eATP: extracellular ATP: EBM: endothelial cell basal medium; EGM: endothelial cell growth medium; ESI: electrospray ionization; GF: growth factor; HSPG: heparan sulfate proteoglycan; HUVEC: human umbilical vein endothelial cell; rh: recombinant human; RLU/s: relative light units/second; SDS-PAGE: sodium dodecyl sulfate polyacrylamide gel electrophoresis.

\section{Acknowledgements}

We would like to thank Prof. Dr. Hans-Ulrich Humpf (Institut für Lebensmittelchemie, Westfälische Wilhelms-Universität, Corrensstrasse 45, 48149 Münster, Germany) for providing the technical equipment used in CD spectroscopy.

We acknowledge support by Deutsche Forschungsgemeinschaft and Open Access Publication Fund of University of Muenster.

\section{Author details}

'Institut für Pharmazeutische und Medizinische Chemie, Hittorfstraße 58-62, 48149 Münster, Germany. ${ }^{2}$ Integrierte Funktionelle Genomik, Interdisziplinäres Zentrum für Klinische Forschung, Röntgenstraße 21, 48149 Münster, Germany.

\section{Authors' contributions}

REG conceived of, designed and carried out all experiments including statistical analysis and drafted the manuscript. SK performed all MS measurements and helped to draft the manuscript. KR participated in the CD spectroscopy analysis and helped to draft the manuscript. KBF participated in the luminometric measurement of ATP. JK initiated the study, participated in conception, design and coordination of the study and helped to draft the manuscript. All authors read and approved the final manuscript.

Received: 9 December 2010 Accepted: 27 May 2011

Published: 27 May 2011

\section{References}

1. Ferrara N, Henzel WJ: Pituitary follicular cells secrete a novel heparinbinding growth factor specific for vascular endothelial cells. Biochemical and biophysical research communications 1989, 161:851-858.

2. Leung DW, Cachianes G, Kuang WJ, Goeddel DV, Ferrara N: Vascular endothelial growth factor is a secreted angiogenic mitogen. Science (New York, NY) 1989, 246:1306-1309.

3. Brown LF, Yeo KT, Berse B, Yeo TK, Senger DR, Dvorak HF, van de Water L: Expression of vascular permeability factor (vascular endothelial growth factor) by epidermal keratinocytes during wound healing. The Journal of experimental medicine 1992, 176:1375-1379.

4. Ravindranath N, Little-lhrig L, Phillips HS, Ferrara N, Zeleznik AJ: Vascular endothelial growth factor messenger ribonucleic acid expression in the primate ovary. Endocrinology 1992, 131:254-260.

5. Carmeliet P, Ferreira V, Breier G, Pollefeyt $S$, Kieckens $L$, Gertsenstein $M$, Fahrig M, Vandenhoeck A, Harpal K, Eberhardt C, et al: Abnormal blood vessel development and lethality in embryos lacking a single VEGF allele. Nature 1996, 380:435-439.

6. Koch AE, Harlow LA, Haines GK, Amento EP, Unemori EN, Wong WL, Pope RM, Ferrara N: Vascular endothelial growth factor. A cytokine modulating endothelial function in rheumatoid arthritis. J Immunol 1994, 152:4149-4156.

7. Detmar M, Brown LF, Claffey KP, Yeo KT, Kocher O, Jackman RW, Berse B, Dvorak HF: Overexpression of vascular permeability factor/vascular endothelial growth factor and its receptors in psoriasis. The Journal of experimental medicine 1994, 180:1141-1146.

8. Ferrara N: Vascular endothelial growth factor. The trigger for neovascularization in the eye. Laboratory investigation; a journal of technical methods and pathology 1995, 72:615-618.

9. Ferrara N, Davis-Smyth T: The biology of vascular endothelial growth factor. Endocrine reviews 1997, 18:4-25.

10. Houck KA, Leung DW, Rowland AM, Winer J, Ferrara N: Dual regulation of vascular endothelial growth factor bioavailability by genetic and proteolytic mechanisms. The Journal of biological chemistry 1992, 267:26031-26037.
11. Poltorak Z, Cohen T, Sivan R, Kandelis Y, Spira G, Vlodavsky I, Keshet E, Neufeld G: VEGF145, a secreted vascular endothelial growth factor isoform that binds to extracellular matrix. The Journal of biological chemistry 1997, 272:7151-7158.

12. Jingjing L, Xue $Y$, Agarwal N, Roque RS: Human Muller cells express VEGF183, a novel spliced variant of vascular endothelial growth factor. Investigative ophthalmology \& visual science 1999, 40:752-759.

13. Whittle C, Gillespie K, Harrison R, Mathieson PW, Harper SJ: Heterogeneous vascular endothelial growth factor (VEGF) isoform mRNA and receptor mRNA expression in human glomeruli, and the identification of VEGF148 mRNA, a novel truncated splice variant. Clin Sci (Lond) 1999, 97:303-312.

14. Lange T, Guttmann-Raviv N, Baruch L, Machluf M, Neufeld G: VEGF162, a new heparin-binding vascular endothelial growth factor splice form that is expressed in transformed human cells. The Journal of biological chemistry 2003, 278:17164-17169.

15. de Vries C, Escobedo JA, Ueno H, Houck K, Ferrara N, Williams LT: The fmslike tyrosine kinase, a receptor for vascular endothelial growth factor. Science (New York, NY) 1992, 255:989-991.

16. Terman Bl, Dougher-Vermazen M, Carrion ME, Dimitrov D, Armellino DC, Gospodarowicz D, Bohlen P: Identification of the KDR tyrosine kinase as a receptor for vascular endothelial cell growth factor. Biochemical and biophysical research communications 1992, 187:1579-1586.

17. Cheng SY, Nagane M, Huang HS, Cavenee WK: Intracerebral tumorassociated hemorrhage caused by overexpression of the vascular endothelial growth factor isoforms VEGF121 and VEGF165 but not VEGF189. Proceedings of the National Academy of Sciences of the United States of America 1997, 94:12081-12087.

18. Carmeliet P, Ng YS, Nuyens D, Theilmeier G, Brusselmans K, Cornelissen I, Ehler E, Kakkar W, Stalmans I, Mattot V, et al: Impaired myocardial angiogenesis and ischemic cardiomyopathy in mice lacking the vascular endothelial growth factor isoforms VEGF164 and VEGF188. Nature medicine 1999, 5:495-502.

19. Ruhrberg C, Gerhardt H, Golding M, Watson R, loannidou S, Fujisawa H, Betsholtz C, Shima DT: Spatially restricted patterning cues provided by heparin-binding VEGF-A control blood vessel branching morphogenesis. Genes \& development 2002, 16:2684-2698.

20. Soker S, Takashima S, Miao HQ, Neufeld G, Klagsbrun M: Neuropilin-1 is expressed by endothelial and tumor cells as an isoform-specific receptor for vascular endothelial growth factor. Cell 1998, 92:735-745.

21. Soker S, Miao HQ, Nomi M, Takashima S, Klagsbrun M: VEGF165 mediates formation of complexes containing VEGFR-2 and neuropilin-1 that enhance VEGF165-receptor binding. Journal of cellular biochemistry 2002, 85:357-368.

22. Klumpp $S$, Kriha D, Bechmann G, Maaßen A, Maier S, Pallast $S$, Höll P, Krieglstein J: Phosphorylation of the growth factors bFGF, NGF and BDNF: a prerequisite for their biological activity. Neurochem Int 2006, 48:131-137.

23. König S, Hasche A, Pallast S, Krieglstein J, Klumpp S: Detection of ATPbinding to growth factors. J Am Soc Mass Spectrom 2008, 19:91-95.

24. Rose K, Litterscheid S, Klumpp S, Krieglstein J: Fibroblast growth factor 2 requires complex formation with ATP for neuroprotective activity. Neuroscience 2009, 164:1695-1700.

25. Hasche A, Ferenz KB, Rose K, König S, Humpf HU, Klumpp S, Krieglstein J: Binding of ATP to nerve growth factor: characterization and relevance for bioactivity. Neurochem Int 2010, 56:276-284.

26. Rose K, Gast RE, Seeger A, Krieglstein J, Klumpp S: ATP-dependent stabilization and protection of fibroblast growth factor 2. Journal of biotechnology 2010, 145:54-59.

27. Rose K, Pallast S, Klumpp S, Krieglstein J: ATP-binding on fibroblast growth factor 2 partially overlaps with the heparin-binding domain. Journal of biochemistry 2008, 144:343-347.

28. Burnstock G: Purinergic signaling and vascular cell proliferation and death. Arteriosclerosis, thrombosis, and vascular biology 2002, 22:364-373.

29. Burnstock G: Historical review: ATP as a neurotransmitter. Trends Pharmacol Sci 2006, 27:166-176.

30. Gerasimovskaya EV, Woodward HN, Tucker DA, Stenmark KR: Extracellular ATP is a pro-angiogenic factor for pulmonary artery vasa vasorum endothelial cells. Angiogenesis 2008, 11:169-182.

31. Rumjahn SM, Yokdang N, Baldwin KA, Thai J, Buxton IL: Purinergic regulation of vascular endothelial growth factor signaling in angiogenesis. British journal of cancer 2009, 100:1465-1470. 
32. Nesterenko MV, Tilley M, Upton SJ: A simple modification of Blum's silver stain method allows for 30 minute detection of proteins in polyacrylamide gels. J Biochem Biophys Methods 1994, 28:239-242.

33. Keyt BA, Berleau LT, Nguyen HV, Chen H, Heinsohn H, Vandlen R, Ferrara N: The carboxyl-terminal domain (111-165) of vascular endothelial growth factor is critical for its mitogenic potency. The Journal of biological chemistry 1996, 271:7788-7795.

34. Brandner B, Kurkela R, Vihko P, Kungl AJ: Investigating the effect of VEGF glycosylation on glycosaminoglycan binding and protein unfolding. Biochemical and biophysical research communications 2006, 340:836-839.

35. Duenas ET, Keck R, De Vos A, Jones AJ, Cleland JL: Comparison between light induced and chemically induced oxidation of rhVEGF. Pharmaceutical research 2001, 18:1455-1460.

36. Rose K: Interaction of ATP with fibroblast growth factor 2: biochemical characterization and consequence for growth factor stability. BMC Biochemistry 2011, 12:14.

37. Thompson LD, Pantoliano MW, Springer BA: Energetic characterization of the basic fibroblast growth factor-heparin interaction: identification of the heparin binding domain. Biochemistry 1994, 33:3831-3840.

38. Keck RG, Berleau L, Harris R, Keyt BA: Disulfide structure of the heparin binding domain in vascular endothelial growth factor: characterization of posttranslational modifications in VEGF. Archives of biochemistry and biophysics 1997, 344:103-113.

39. Sakiyama-Elbert SE, Hubbell JA: Controlled release of nerve growth factor from a heparin-containing fibrin-based cell ingrowth matrix. J Control Release 2000, 69:149-158.

40. Rose K, Kriha D, Pallast S, Junker V, Klumpp S, Krieglstein J: Basic fibroblast growth factor: lysine 134 is essential for its neuroprotective activity. Neurochem Int 2007, 51:25-31.

41. Seye Cl, Yu N, Gonzalez FA, Erb L, Weisman GA: The P2Y2 nucleotide receptor mediates vascular cell adhesion molecule-1 expression through interaction with VEGF receptor-2 (KDR/Flk-1). The Journal of biological chemistry 2004, 279:35679-35686.

42. Boeynaems JM, Communi D, Gonzalez NS, Robaye B: Overview of the P2 receptors. Semin Thromb Hemost 2005, 31:139-149.

doi:10.1186/1471-2091-12-28

Cite this article as: Gast et al: Binding of ATP to vascular endothelial growth factor isoform VEGF- $A_{165}$ is essential for inducing proliferation of human umbilical vein endothelial cells. BMC Biochemistry 2011 12:28.

\section{Submit your next manuscript to BioMed Central and take full advantage of:}

- Convenient online submission

- Thorough peer review

- No space constraints or color figure charges

- Immediate publication on acceptance

- Inclusion in PubMed, CAS, Scopus and Google Scholar

- Research which is freely available for redistribution 